\title{
INTRIGUES BEHIND THE HAREM WALL: SOCIAL, CULTURAL AND POLITICAL CONSTRUCTION OF LIFE BEHIND THE HAREM OF SULTAN SULAIMAN I
}

\author{
Eka Hendry Ar. \\ Pontianak State Institute of Islamic Studies
}

\begin{abstract}
The urgency of exploring the history of the harem is important, not only because of being a rare phenomenon today or no longer in existence but perhaps this work is like opening the pandora's box, a nightmare for women. This paper is presented as an academic review to portrait the fact that power is always in contact with wealth and attractive women, especially during a period when patriarchy was dominant. Sultan Sulaiman I was in power between 1520 to 1566 AD, in the 16 th century AD. In western literature, Sultan Sulaiman was known as Suleyman the Magnificent. The work concludes, first, that the harem to the people of the Middle East in the medieval times was considered respectable for the family, especially for women both in the context of the imperial and domestic harem, where it was constructed in the name of honor, comfort and safety for women. Second, the construction of social, cultural and religious institutions of harem is the integration between the will to protect and maintain the honor of women, the concept of marriage in Islam and the patriarchal system hegemony in the Islamic world particularly in the context of the imperial harem. Third, the role of Sulaiman I who was "brave" to go against the tradition that had been practiced for many years in the Ottoman Empire, a milestone was important for the emancipation of women of the harem. Finally, to respond to the harem tradition, we must be in an impartial position, between the construction of the West and East.
\end{abstract}

Keywords: Harem, Sultan Sulaiman I, construction, Islamic Sultanate.

\section{INTRODUCTION}

When I read the history of the development of the Islamic sultanate, my attention centered on the private lives of the sultans, particularly on the portarait of the lives of women in the Sultan's Harem. One might question the urgency of exploring the history of the harem, because in addition to being a rare phenomenon nowaways (or no longer in existence) perhaps this work is like opening the pandora's box, a nightmare for women. This paper is presented as an academic review to portrait the fact that power is always in contact with wealth and attractive women, especially during a period when 
patriarchy was dominant. This study seeks to investigate true meaning of the harem in social, cultural and religious views of the Middle Eastcommunities in the Islamic medieval period. I will also make an effort to reconstruct the structure of the harem institution and social functions that existed behind the harem. Finally, the article will explore the intrigues that developed among the harem dwellers in order to maintain the status quo or the struggle for influence (and power) in the harem.

To limit the scope of this paper, I focus on the period of Sultan Sulaiman 1, the 10th Ottoman Caliph. Sultan Sulaiman was in power between 1520 to $1566 \mathrm{AD}$, in the 16th century AD. In western literature, Sultan Sulaiman was known as Suleyman the Magnificent. Karen Armstrong (2002: 155) called him Sulaiman al-Qanuni (the Decision Giver). Supposedly it was recorded in some historical literature, during his reign, the Ottoman Caliphate successfully annexed several areas such as Belgrade, Rhodesia, Hungary, a large part of the Middle East, North Africa, the Mediterranean, the Red Sea and the Persian Gulf. Karen Armstrong (2002: 155) argued that, at the time of Sulaiman, the Utsmaniah Kingdom reached its expansion peak. The peak cultural awakening of this dynasty was marked by the works of fundamental architecture, such as palaces and large mosques scattered throughout the country. In addition, the leadership of Sulaiman I's first period was also marked by advancement in the field of art (paintings), history, medicine and astronomy which was marked by the construction of the observatory (1579). Karen Armstrong also noted that the achievement in this period also included the field of religion, such as the implementation of Islamic Sharia as the official law for all Muslims all over the country.

Besides his popularity in the conquest of the region and the development of civilization, Sulaiman I was also popular with his harem which was filled with beautiful women of different countries. Sulaiman's Harem had its own story, which is no less interesting than the success of anexation of areas outside of Turkey. Colin Falconer discussed this reality in the fictional form about the intrigues and competition among the women in the Sulaiman's Harem in a novel entitled Sulayman's Harem.

What is important to note is that also during the period of leadership of Suleiman I there was "courage" to change the tradition ingrained in the system of the Ottoman empire, the habit of a king having one son. Colin Imber (2012: 121-122) wrote that, most of the successors to the Ottoman Empire were a child from the slaves. Then since the 14th and 16 century, there was a tradition that restricted a king to sleep with a wife who had given a son to the king. Sons from different mothers would live separately, until then they were aged 10, 11 
and 12 years, then the Sultan would appoint them as governor of a province, accompanied by his mother who had a great influence. At the time of Sultan Suleiman I, the habit began to change, not for political reasons, but rather for romantic. The Sultan had a son from a different wife (1521), Mustafa of a slave named Mahidevran, and Mehmed of European origin Hurrem named Roxelana. In the previous tradition, the Sultan was no longer allowed to sleep with both the mothers of his sons, but Sulaiman was "against" the tradition. Evidently, between 1522 and 1531, he had other 6 children, including Selim II (1566-1577). In fact, because he loved Roxelana so much that when she died in 1558, he was buried her in the yard of the mosque of Sulaiman, next to the Tomb of the Sultan. (Colin Imber, 2012: 122)

Sulaiman first action was considered against the tradition that had for many years been practiced by the family court, even according to Colin, it was a "scandal" at that time. These changes, in the future were not just about changing a tradition, but fundamentally changing the policies and political structures of the the dynasty, and opened a larger space for the Hurrem (or women) to take on a greater role in the political power of the empire. These women not only became a concubine, but also took on the role as the queen mother when he died and had a great influence on his son (the subsequent ruling Sultan).

What were the role and the conspiracy of the women in a fight for influence of the Sultanate during the period of Sulaiman I is the focus of study in this paper. This phenomenon is examined with a critical historical perspective. This historical phenomenon was reviewed with several theories such as the theory of conflict (especially on competition) and contemporary conspiracy theory. The urgency of this piece of writing, despite the focus of the study being on the history of the 16th century, is that the motive of such conflicts is commonly found in the modern era today.

\section{HAREM IN THE SOCIAL, CULTURAL AND RELIGIOUS FRAME OF THE MIDDLE EAST SOCIETY}

Before going any further, we need understand what a harem is. There are several definitions of the harem including origins of the term itself. Harem is a term in the Turkish language, which was derived from Arabic: مرح haram meaning a forbidden place, sacred, holy, related to Pى Harim, a place that should not be inviolable, female members of the family and مارح Haram (forbidden and sacred). (Tati Rohayati et al., 2013). While there are other opinions arguing that, the word Haram (Arabic) or harem (in English) means 'to live isolated from the outside world and illustrates the oxymoronic shelter for women who are also imprisoned inside impenetrable walls. (Elizabeth Abbott, 2013: 53) Haram or harem was found not only in the Middle East Sultanate, but also in 
the Empire of China.

Mernissi Fajarwati made distinctions of harem into two categories: the royal harem (imperial) and regular harem (domestic) (Ana Bilqis Fajarwati, 2013: 60; Fatima Mernissi, 1999: 37). The imperial Harem is a palace owned by rich and powerful men who bought hundreds of female slaves and kept them in an environment with a harem guarded by castrated eunuchs. Meanwhile a regular harem (domestic) is a graceful walled house, not a palace, without the eunuchs and slaves. The house is inhabited by a large family with a view to preventing women to have contact with the outside world.

Mernissi's version of the categorical distinction is motivated by the need to clarify the stereotypical views of the West whose opinion of the Islamic kings of in the Middle East and the Maghreb (North Africa) still perpetuating the harem institution. The Western society still thinks that a harem is filled with the king's concubines, amounting to tens, even dozens of women and their children. According to Fatima Mernissi (in Ana Bilqis Fajarwati, 2013: 60) the imperial harem has long been extinct, since World War I and the collapse of the Ottoman Empire due to the ban by Western powers. Meanwhile, the domestic harem remains until today, along with the "theological beliefs" rooted in cultural factors to maintain and facilitate the process of keeping wives and daughters from outside influences.

The harem whatever the form (read: imperial and domestic) there is a passion to keep a distance between men and women. According to Mernissi, the Arabs had a culture that explicitly distinguishes between "space" for both men and women. This is, according to Mernissi, not merely the "arrogance" of men, but rather the spirit of keeping the lineage and honors. However, in a society that is running the harem tradition, the position of men is superior, so the harem is identified with a form of deprivation of women's rights by men.

The construction of social structure in the harem is an integration of elements of Turkish medieval culture that put the position of men, especially the Sultan in a very high position and superior and the elements of the Islamic faith with Sharia rules about marriage and "protection" against the honor of women even though, to most of us who live in the modern era will interpret this phenomenon as a reflection of the "arrogance" of men against women. I wrote term "protection" in quotation marks, because of the desire to preserve the honor has a very slight difference with "oppression", "restraint" or "control" of men (in this context Sultan) against women who live in the Harem.

Although the real information about life of women in the Sultan's harem is very limited, speculation and myth thrive on harem life. Christine Isom- 
Verhaaren (2006: 178-179) suggested that, Western writers, including those who had visited and even lived "close" to the Ottoman Sultan, still did not know about life in the harem. During Murad III's reign, it was mentioned there was a European doctor named Domenico Hierosolimitano who seved as the Sultan's doctor. He then wrote an article entitled Relation in around 1611 in Rome. This work then was plagiarized by subsequent authors. This work is regarded as an inaccurate depiction of the life of the women in the harem.

Regardless of the inaccurate information about the harem, various myths about the lives of the harem of the Sultan developed in Europe. The construction of the Western writers about the harem of Sultan was more pejorative, because the harem was described as a symbol of oriental despotism. Several authors such as Domenico of Jerusalem, Mostesquieu and Paul Rycaut wrote that the imperial harem of the Ottoman Empire was a symbol of the Middle East, characterized by the tyrannical government and suppression of women (Christine Isom-Verhaaren (2006: 160-161). As a result of poor accurate information about the lives of women in the harem of the Sultan, and may be a bias of "sentiment" of the West against the Ottoman Empire, in my opinion, has prompted many negative stereotypes about the Sultan and his harem life. In other words, the construction of the West against the life of the Sultan and his harem (the harem derived mainly from the West) further highlights the role of the women (hurem) and cornered the Sultan and the harem tradition itself.

\section{CONSTRUCTION STRUCTURE AND FUNCTION OF SOCIAL INSTITUTION IN IMPERIAL HAREM}

The view of the harem is prone to bias of interests of both on the basis of gender and cultural values of a society. Diane M. Huddleston (2012: 1-5) argued that the Western writers (especially male writers) of the 18th and 19th century who had the opportunity to visit the Middle East wrote a lot of things such as the cultural sites, flora and fauna as well as the beauty of natural scenery. However, a theme that they were not allowed to talk about was the harem. As a result, the writing of a harem was then vulnerable to the belief of the hegemonic culture and religion of the West that tend to refuse the East. In other words, the assessment of women and harem life in the Middle East was written with "prejudice" of the West against the East, or in the term coined by Diane (2012: 1) with imagination and fantasy, and not based on a true reality. This view was recently changed after some Western female writers began to write about it because they were allowed to enter the world of the harem, observing it and then writing about the lives of women and the harem which was then known as the harem literature. 
During the reign of Caliph Sulaiman 1 (16th century AD), the harem was an educational institution that was devoted to women. In the harem women were taught art and science of reading, writing, dancing, painting, and protocols. All financial needs of the women in the harem were borne entirely by the kingdom. In the Ottoman system of government, the central government was the residence of Osman, which consisted of the servants of the Emperor, the Imperial Harem, and the Palace School. The mother of the sultan (Valide Sultan) held the highest power over the Harem. Therefore, she had a very strong position in court (Tati Rohayati et al., 2013)

In the palace of the Turkish Ottoman Empire, there was demarcation of the area which became the authority of men and women's regional authorities. Only the Sultan was free to both areas. The area for men was called Selank (or Selanik) the place where the king and the princes held royal activities and including religious rituals. The area for women was the harem or darus saade (home of happiness). (Miftahus Shurur, 2013). Furthermore, according Miftahus Shurur, the harem was the area built with a shape like apartments. In the Ottoman Empire, the harem was built within the Topkap Palace and Dolmabahçe Palace. The position of the Topkap harem in a palace was located on the right wing from the Topkapi palace which was right behind the imperial council building with the justice tower as a symbol of justice for officials and employees who violated the law. Whereas in Dolmabahçe palace, the harem was located at the rear of the palace, behind the Selank. According Miftahus Shurur (2013), the position or location of the harem had influence on the lives of the royals. The position of the royal harem at the Topkapi was far more influential than the harem position in Dolmabahçe palace.

According to Shurur (2013), the women who would inhabit the harem came from a variety of backgrounds, not always from the nobility. According to Elizabeth Abbott (2013: 55) women and eunuchs who lived in the harem came from diverse ethnic and racial backgrounds such as Russian, Circassian, Tartar, Greek, Serbian, Italian, Nubian and Ethiopian, and the largely Christian. One thing that I find surprising is that none of these women and eunuchs was Muslim, because slavery was prohibited by law.

Most of them were prisoners of war or purchased from the slave market or a gift from Governors under the rule of the Ottoman Empire. The beautiful women before entering the Harem had to go through several stages and status. First, they got an acemi status (beginner), which was closely monitored by kahya $k a d n$ (female supervisors). While undergoing the acemi status, they received a variety of education such as religious education, ethics, morals, skills (such as sewing, embroidery, playing music, storytelling and including how to "serve" 
the Sultan). After passing the beginner status, they would proceed to the next status as cariye sagird gedikli and usta. The rise in status was based on several qualifications such as the level of expertise and the time spent at the Harem.

The status affected the closeness to the Sultan as he would choose those who had achieved the status of Usta. Sometimes, those chosen by the Sultan later became his wife got a title of has odalk or Haseki. The Haseki had access and influence over the decisions of the Sultan, both the decision concerning the harem and political decisions. Shurur said that Sultan's wives could affect the Ferman (decree) of the Sultan. In this context, opportunities of intrigue occurred among the dwellers of the harem, fighting for influence in front of the Sultan. This section will be discussed in depth at the end of this paper.

The Harem of the Sultan of Turkish Ottoman Empire was inhabited by several elements i.e. the Sultan, the valide sultan, Kadin, Iqbal, Concubines and odalisques and eunuchs. The women's hierarchy in the harem is listes below.

1. Valide Sultan (Queen Mother) was the Sultan's mother who had the highest position. She had occupied the second position after her son. In the old palace, the queen mother was the highest ruler. The queen mother communicated with the concubines of his son not directly but through the middle person called Kizlar Agha which means the general of the girls, a black chief eunuch (Elizabeth Abbott, 2013: 54).

2. Kadin, the Sultan's favorite women who had the privilege as a wife of Sul$\tan$.

3. Iqbal, the favorite mistress who gave birth to a boy.

4. Concubines, beautiful women presented to the Sultan and served the Sultan at least once.

5. Odalisques, a virgin slave girl purchased in the market and then presented to the Sultan. If after the "dedication" period (haing reached 9 years) and the Sultan no longer needed her, a slave could leave the harem to get married.

In addition to women, the harem also had eunuch, and most of them were slaves from Africa who had been castrated. They were also called Mujhubs, men without a penis. (Elizabeth Abbott, 2013: 56) The task of this Kasem was serving all the needs of women in the harem, except for the purposes of sex. The employees of the harem had the facility from the kingdom such as salary and accommodation needs and consumption. They also wore uniforms that represented the position and status in the royal administration. 


\section{INTRIGUE AND DEVIATIONS BEHIND THE HAREM WALL}

The systems and structures applied in the harem, and many beautiful women who lived there, of course, raised many problems. Moreover, the pattern of life in the harem was far from normal life, like the relationship of men and women outside the palace. So many beautiful women, filled with all the necessities of life, except sex, who were attended and serviced by Kasim who had been castrated, of course, became a factor for possible behavior deviations such lesbian behavior and other sexual deviations. Since they grew up in the harem, they would be encouraged to compete to be the best and had the opportunity to be the closest to the Sultan. Moreover, there were a lot of the inhabitants of the Harem. Elizabeth Abbott (2013: 54) wrote that during the reign of Sultan Sulaiman, the number of women in the harem was 3000. In such conditions, competition and intrigue among beautiful women were inevitable.

At the time of Sultan Sulaiman I (1520-1566) there was a very famous woman named Roxelana, a woman who was said to come from Poland. Galina I. Yermolenko (2009: 1) wrote that the story of Roxelana (in Western literature written Roxolana) spread in the form of legend and controversy in the 16 th century. This legend about the role which was considered remarkable (extraordinary woman), not only as the most beloved wife of Sultan Suleiman I, but she also recognized to have political and social influence. What Galina put forward was also supported by Abbot's recount. According Elizabeth Abbott (2013:53) in Poland there was a story about a woman named Alexandra Lisowska, daughter of an Orthodox priest who was poor and lived in Rohatyn, Ruthenia, in the Carpathian Mountains. In an attack by the Tartars to the area, Alexandra captured by the Tartar troops and then sold to the Great Sultan of the Turkish Ottoman Empire. Alexandra was then known by the name Roxelana.

Simon Sebag Montefiore (2012: 382) made a contemporary portrait of Roxelana as a pastor's daughter who was kidnapped in Poland and sold to the Sultan's Harem. She was not pretty, but graceful and direct. She had a round face, wide eyes and lips like roses. She was known as a woman who was romantic, so as to attract the attention of Sulaiman. Her romantism appeared in the poems sent to the Sultan. She occupied the position of second qadin or concubine of the king, while the first concubine was a Tartar woman named Gulbahar (in Turkish meaning the rose of the spring season). In her position as first Qadin, Gulbehar who was the mother of Prince Mustafa, held the first position. Prince Mustafa was heir to the throne. To Roxelana, Gulbehar was a barrier for her to become a major concubine of Sulaiman. In recorded history, Roxelana played intrigue on how to get rid of Gulbehar. Among the 
intrigue she used was provoking Gulbehar to get into a fight with her. When Gulbehar committed violence againt Roxelana, Gulbehar was trapped in the "game" played by Roxelana. Roxelana deliberately did not fight Gulbehar back, resulting in traces of violence on her face and body. When the news got to the ears of the Sultan, he was furious and then expelled Gulbehar out of the Harem. The conflict between Roxelana and Gulbehar was an example of how political intrigue going on among the dwellers of the harem to gain access and closeness to the Sultan.

According to Elizabeth Abbott (2013: 58) Roxelana continued to spread "poisonous roses", with her involvement in the murder of people near Sulaiman such as Ibrahim Pasha, a trust, a leader and brother-in-law of Sulaiman. Roxelana was also involved in the assassination attempt against Prince Mustafa, who was a legitimate heir to Sulaiman's throne. Roxelana did that because she wanted to save her sons from the threat of fratricide. Roxelana managed to fulfill her desire, including influencing many of the Kingdom's policies. Seme observers condemned her, some also praised her. She was condemned for playing foul intrigue, making harem politics poisonous, the term Elizabeth Abbott coined (2013: 60). She was praised because she had shown that a woman could influence the harem tradition with a strong tradition of patriarchal hegemony of men.

\section{CLOSING REMARKS}

Based on the review of the literature above, I have come to some conclusions, as follows: First, the harem to the people of the Middle East in the medieval times was considered respectable for the family, especially for women both in the context of the imperial and domestic harem, where it was constructed in the name of honor, comfort and safety for women. Second, the construction of social, cultural and religious institutions of harem is the integration between the will to protect and maintain the honor of women, the concept of marriage in Islam and the patriarchal system hegemony in the Islamic world particularly in the context of the imperial harem, The harem walls were not merely a space of privacy for women, but also symbolized "domination" or superiority of men (especially the Sultan) over women. The slight difference between privilage and honor for women with "suppression" or confinement. To those who live in the modern world, it is difficult to understand this phenomenon, especially in the view of "concern" over the position of women. I am well aware of the very wise judgment on the historical events of then past, with the standard set of values that they profess, with a more modern emancipatory perspective.

Third, the role of Sulaiman I who was "brave" to go against the tradition that 
had been practiced for many years in the Ottoman Empire, a milestone was important for the emancipation of women of the harem. Although during period of thr previous the sultanate earlier, the political role of women was not completely turned off, which was proved by the mother of the prince who was appointed as governor in the region, and had an important role for his son. However, under the reign of Suleiman I, the role of harem women was more important, especially in determining the power of the Sultan's journey. This also became a "battle field" for the women of the harem to fight for access to the center of power, namely closeness to the Sultan, especially if the Hurem had the intelligence and skill to read the situation and take the role. Hurem Roxelana was an example, an intelligent woman who could read and utilize the opportunities given by the Sultan. The Western literature, although aware of the controversial side on the one hand, but on the other hand, showed respect to Roxelana a European woman who had an important role in the Turkish Empire. Perhaps this is a great honor, but may also be a form of "cynicism" against the hegemony of the Ottoman Empire which was considered a "threat" to the Western world. In a simple phrase, "a grand Turkish Sultan was subject to a European Christian woman's love, who is no-one but a slave from Poland".

Finally, to respond to the harem tradition, we must be in an impartial position, between the construction of the West and East. The construction of the Western writers tends to be negative about the harem, where it is regarded as a symbol of government tyranny and repression against women's freedom. However, the information that formed the basis of the construction was very little, due to the limited access of the visitors, writers and historians to the domestic life of the imperial harem. Meanwhile the construction of Eastern community (read: the Middle East) of the imperial harem or domestic harem is a form of protection for women in order to honor and glorify them. In my opinion, the reason is also too apologetic and misogynistic, because it reflects the perspective of men (or ruler of men), rather than representing the perspective of women. An impartial attitude toward the construction will of course allow us to interpret the historical events of the past in a fair and wise manner. Wa Allah a'lam bi shawab.

\section{REFERENCES}

Ana Bilqis Fajarwati. 2013. "Islam dan Demokrasi Membaca Pemikiran Fatima Mernissi" in Jurnal Religio Jurusan Perbandingan Agama of Faculty of Ushuluddin IAIN Sunan Ampel Surabaya. Volume 03. Nomor 01. 
Tahun 2013 page: $60-78$.

Christine Isom-Verhaaren. 2006. "Royal French Women in the Ottoman Sultans' Harem: The Political Uses of Fabricated Accounts from the Sixteenth to the Twenty-first Century" in Journal of World History of the University of Hawai'i Press. Vol. 17, No. 2 Tahun 2006. Page: 72-83.

Colin Imber. 2012. Kerajaan Ottoman, Struktur Kekuasaan Sebuah Kerajaan Islam Terkuat dalam Sejarah. Jakarta: PT. Elex Media Komputindo Kompas Gramedia.

Diane M. Huddleston. 2012. “The Harem: Looking Behind the Veil.” Department of History Seminar Paper. Oregon: Western Oregon University.

Elizabeth Abbott. 2013. Wanita Simpanan: Kontroversi Selingkuhan Tokoh-Tokoh Dunia, dari Orang Suci Hingga Politisi, dari Zaman Kuno hingga Era Kini. Jakarta: Alvabet (translation).

Fatima Mernissi. 1999. Teras Terlarang (Kisah Masa Kecil Seorang Feminis Muslim). Bandung: Mizan (translation).

Karen Armstrong. 2002. Islam: A Short History (Terjemahan: Sepintas Sejarah Islam). Yogyakarta: Ikon Teralitera (translation).

Philip K. Hitti. 2002. History of The Arabs (Edisi Revisi 10). Jakarta: PT Serambi Ilmu Semesta.

Simon Sebag Montefiore. 2012. Jerusalem The Biography. Jakarta: Alvabet (translation).

\section{Internet:}

Galina I. Yermolenko. 2009. Reading the Other: Roxolana In European History and Literature. Retrieved from http://www.nssa.us/journals/2009-32-1/2009-32-1-22.htm diakses 29 October 2015.

Miftahus Shurur. Hareem. Retrieved from: http://ppiturki.tripod.com/edisiiii/id7.html. 23 May 2013.

Gianna Carotenuto. Domisticating The Harem. Retrieved from: (http://www. international.Ucla.edu/asia/news/article.asp?parentid=93148) on 23 May 2013.

Tati Rohayati dkk. Dua Sisi Harem: Penghibur dan Pengatur Sultan. Retrieved from: (http://cacingpadangpasir.blogspot.com/2013/06/dua-sisi-harem-penghibur-dan-pengatur.html) on 3 July 2013 